Annals of the Rheumatic Diseases, 1984, 43, 651-652

Case report

\title{
Use of anti-idiotypic antibodies to demonstrate rheumatoid factor producing bone marrow cells in essential mixed cryoglobulinaemia
}

\author{
A. E. GHARAVI, G. CAMPION, AND G. R. V. HUGHES \\ From the Rheumatology Unit, Royal Postgraduate Medical School, Hammersmith Hospital, Du Cane Road, \\ London W12 OHS
}

SUMMARY Specific cells producing rheumatoid factor (RF) were demonstrated in a bone marrow preparation of a patient with essential mixed cryoglobulinaemia. This was achieved by the use of labelled anti-idiotypic antibodies raised against purified RF from the patient's circulating cryoglobulin. This technique may be applicable to other diseases in which specific antibodies are pathogenetically implicated. The more precise demonstration of specific antibody-producing marrow cells may in addition have therapeutic implications.

Anti-idiotypic antibodies are thought to play a significant role in the homoeostatic self-control or 'network' system of antibody production. ${ }^{1}$ In addition to their role in immunoregulation they may have potential use in therapy through the specific suppression of antibody-producing B cell clones. ${ }^{2} 3$ A further potential use for anti-idiotypic antibodies is in diagnosis.

In this preliminary communication we report the demonstration of antibody-producing cells in the marrow of a patient with essential mixed cryoglobulinaemia. This was achieved by the use of anti-idiotypic antibody to rheumatoid factor isolated from the patient's cryoglobulin.

\section{Patients and methods}

A 56-year-old man was referred to the Hammersmith Hospital with a severe purpuric rash of the lower limbs and renal failure. Investigations revealed a heavy cryoprecipitate $(5 \cdot 3 \mathrm{~g} / \mathrm{l})$. This contained monoclonal IgM (k chain) with rheumatoid factor (RF) activity and polyclonal IgG. Additional findings were hypocomplementaemia and impaired renal function.

A diagnosis of essential mixed cryoglobulinaemia

Accepted for publication 24 January 1984. Correspondence to Dr G. R. V. Hughes. was made, with associated renal failure. Treatment with plasmapheresis and immunosuppression was instituted.

PREPARATION OF RHEUMATOID FACTOR

The IgM RF was separated by dissolving the cryoprecipitate in $0.1 \mathrm{M}$ acetate buffer $\mathrm{pH} 4$ and gel filtration on Sepharose 6 B (Pharmacia) equilibrated with the same buffer. The $19 \mathrm{~S}$ fraction contained monoclonal IgM (k) with RF activity. This fraction was cryoprecipitable only when human or rabbit IgG was added to it.

PREPARATION OF ANTI-IDIOTYPIC ANTIBODY Anti-idiotypic antibody was raised in a rabbit by immunisation with the whole IgM RF molecule. This antiserum was immunoabsorbed with solidphase pooled normal human immunoglobulin and with IgM (k) paraprotein without rheumatoid factor activity. By the Ouchterlony technique it was shown to react only with IgM RF.

The antiserum was then fractionated and pepsindigested and $F\left(a b^{\prime}\right)^{2}$ IgG was prepared. The F $\left(a b^{\prime}\right)^{2}$ anti-idiotype was conjugated with fluorescein for bone marrow staining.

BONE MARROW STUDIES

Marrow aspiration revealed no abnormalities on routine haematoxylin-eosin staining. 


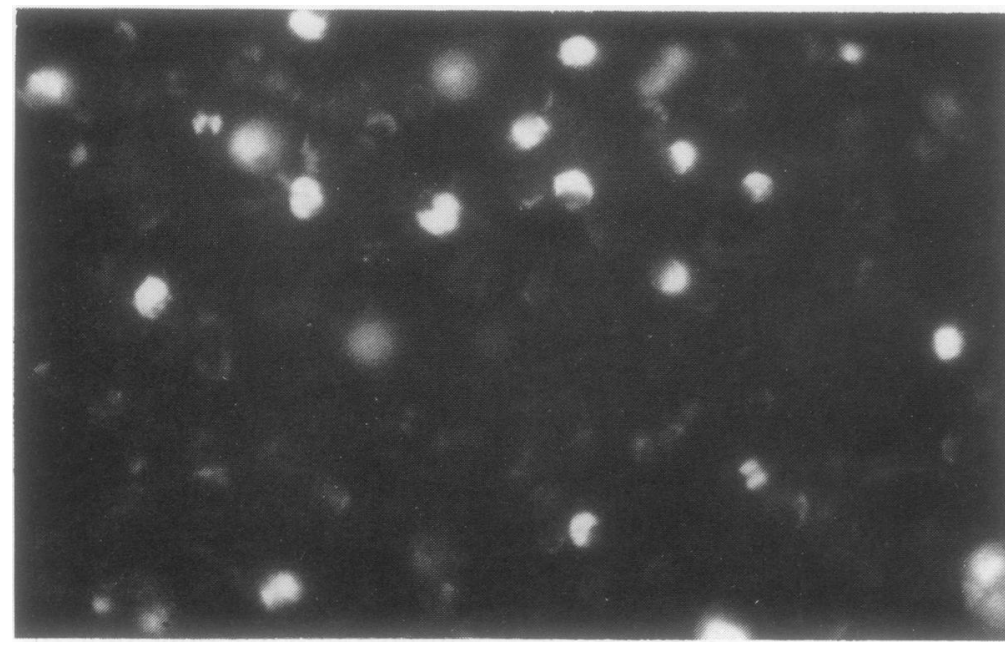

Fig. 1 Bone marrow smear of the patient stained with fluorescein labelled anti-idiotype.

The bone-marrow preparations were then studied by direct immunofluorescence with conjugated $F$ $\left(\mathrm{ab}^{\prime}\right)^{2}$ IgG anti-idiotype preparation. Between 7 and $9 \%$ of the total nucleated cells in the bone marrow $(\mathrm{N}=0-3 \cdot 5 \%)$ showed positive cytoplasmic staining (Fig. 1).

In another set of experiments the patient's peripheral blood lymphocytes in suspension were incubated with IgG anti-idiotype with and without guinea-pig complement. Staining with fluoresceinlabelled goat anti-rabbit antibody showed the destruction of the lymphocytes only in the presence of complement.

\section{Discussion}

This study describes the use of anti-idiotypic antibody to demonstrate rheumatoid-factor producing cells in the bone marrow in human disease. While conventional bone marrow staining had failed to reveal any abnormalities, the use of idiotypic antibody specifically directed against rheumatoid factor revealed a population of marrow-cells putatively producing the RF.

The technique of cell labelling by anti-idiotypic antibodies appears to have potential use in a variety of autoimmune diseases such as Goodpasture's syndrome, myasthenia gravis, autoimmune haemolytic anaemia, and possibly systemic lupus erythematosus. It is also conceivable that, by attachment of cell poisons such as ricin $\mathrm{A}^{4}$ to such anti-idiotypes, killing of specific antibody-producing cell clones might become feasible.

We are grateful to the Arthritis and Rheumatism Council and to Messrs May and Baker for their financial support, and to Dr A Beardwell, Dr R. Bernstein, and Mr B. Patel for their help in the clinical and laboratory studies.

\section{References}

1 Jerne N K. Towards a network theory of the immune system. Ann Immunol Paris 1974; 125C: 373-89.

2 Brown C A. Carey K. Colwin R B. Inhibitions of autoimmunc tubulointerstitial nephritis in guinea pigs by heterologous anti-sera containing anti-idiotypic antibodies. J Exp Med 1979; 123: 2101-7.

3 Fuchs S. Immunosuppression of experimental myasthemia gravis. In: Dan P C. cd. Plasmapheresis and the immunobiology of myasthemia gravis. Boston: Houghton Mifflin, 1979: 20.31.

4 Vitteta E S. Krolick K N, Uhr J W. Neoplastic B cells as targets for antibody-ricin A chain immunotoxins. Immunol Rev 1982; 62: $159-83$. 